\title{
Ostracode Biostratigraphy of Upper Campanian (Cretaceous) Marine Sediments from the Millhaven Core, Screven County, Georgia
}

By Gregory S. Gohn

U.S. GEOLOGICAL SURVEY PROFESSIONAL PAPER 1603-E 


\section{CONTENTS}

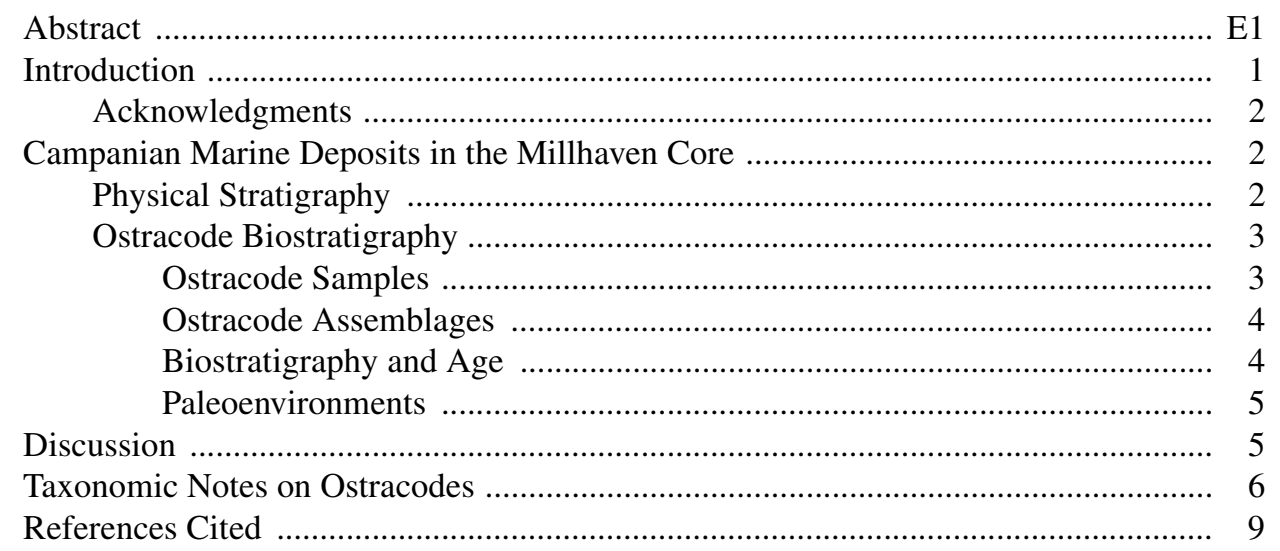

\section{PLATE}

[Plate follows References Cited]

1. Selected Cretaceous ostracodes from the Black Creek Group in the Millhaven core, Screven County, Georgia.

\section{FIGURES}

1. Index map showing location of the Millhaven test hole in Georgia and additional test holes in Georgia and South

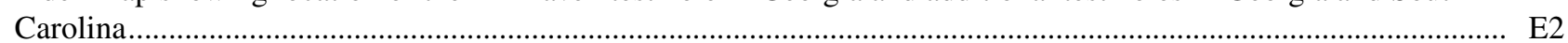

2. Geophysical logs and geologic units of the Cretaceous section in the Millhaven core to a depth of 1,452 feet............. 3

3. Chart showing ostracode interval zones and associated ostracode datums................................................................ 5

\section{TABLE}

1. Cretaceous ostracodes from the Black Creek Group in the Millhaven core, Screven County, Georgia 


\title{
Ostracode Biostratigraphy of Upper Campanian (Cretaceous) Marine Sediments from the Millhaven Core, Screven County, Georgia
}

\author{
By Gregory S. Gohn
}

\begin{abstract}
The Cretaceous section in the Millhaven core from Screven County, Georgia, contains calcareous, fine-grained marine deposits in part of the interval assigned to the Black Creek Group. These calcareous deposits and associated overlying and underlying deposits between depths of 1,119 and $927 \mathrm{ft}$ are designated informally as Black Creek subunit 2 by Falls and Prowell (this volume, chap. A).

Two informally named ostracode assemblages are present in Black Creek subunit 2 between depths of 1,043 and $975 \mathrm{ft}$ : an older Haplocytheridea everetti assemblage and a younger Haplocytheridea sarectaensis assemblage. The presence of Escharacytheridea pinochii (Jennings) in the lowest studied sample and the presence of Fissocarinocythere pidgeoni (Berry) in higher samples indicate a late Campanian to Maastrichtian age for the interval between 1,043 and 1,015 ft. This age is compatible with the late Campanian age assigned to the calcareous part of Black Creek subunit 2 by Bukry (this volume, chap. D; calcareous nannofossil Zone CC 22). Both ostracode assemblages are strongly dominated by various species of Haplocytheridea and related genera that suggest inner-neritic paleoenvironments of deposition for the sediments of Black Creek subunit 2.

The total range of the ostracode Haplocytheridea sarectaensis Brown is within the upper parts of intervals assigned to calcareous nannofossil Zone CC 22 in the Millhaven section and in previously studied test holes in central South Carolina. The top of Zone CC 22 is slightly older than the Campanian-Maastrichtian Stage boundary as defined by J.A. Burnett and others (1992, Newsletters on Stratigraphy, v. 27, p. 157-172). Hence the highest occurrence of $H$. sarectaensis Brown approximates this stage boundary in eastern Georgia and central South Carolina. Sections in central South Carolina containing H. sarectaensis Brown and
\end{abstract}

calcareous nannofossil Zone CC 22 are within the Donoho Creek Formation of the Black Creek Group.

\section{INTRODUCTION}

The U.S. Geological Survey (USGS), in cooperation with the U.S. Department of Energy (USDOE) and the Georgia Geologic Survey of the Georgia Department of Natural Resources, conducted a study of ground-water flow and ground-water quality in the area of eastern Georgia that is adjacent to the USDOE Savannah River Site in South Carolina (fig. 1). This study addressed concerns by the State of Georgia regarding the potential for movement of ground water containing radionuclides or other contaminants from the Savannah River Site into Georgia through coastal plain aquifers passing beneath the Savannah River (Clarke, 1992, 1995).

A principal component of the study was the hydrologic and geologic analysis of test hole clusters drilled in the coastal plain sediments of Burke and Screven Counties, Ga. (fig. 1). The hydrologic studies at the cluster sites included determinations of hydraulic properties, pressure heads, and water quality for multiple aquifers (Clarke and others, 1994, 1996; Leeth and others, 1996). The geologic studies included lithologic, paleontologic, and stratigraphic analyses of the Cretaceous and Cenozoic sediments in continuously cored sections at each site. These geologic analyses were conducted to determine the physical characteristics, distributions, and correlations of the several aquifers and confining units. This report discusses the ostracode biostratigraphy, inferred depositional paleoenvironments, and regional correlation of Cretaceous calcareous marine sediments present in the Millhaven test hole in northern Screven County, Ga. (fig. 1).

The Millhaven stratigraphic test hole was completed by a USGS drill crew in February 1992 to a depth of 


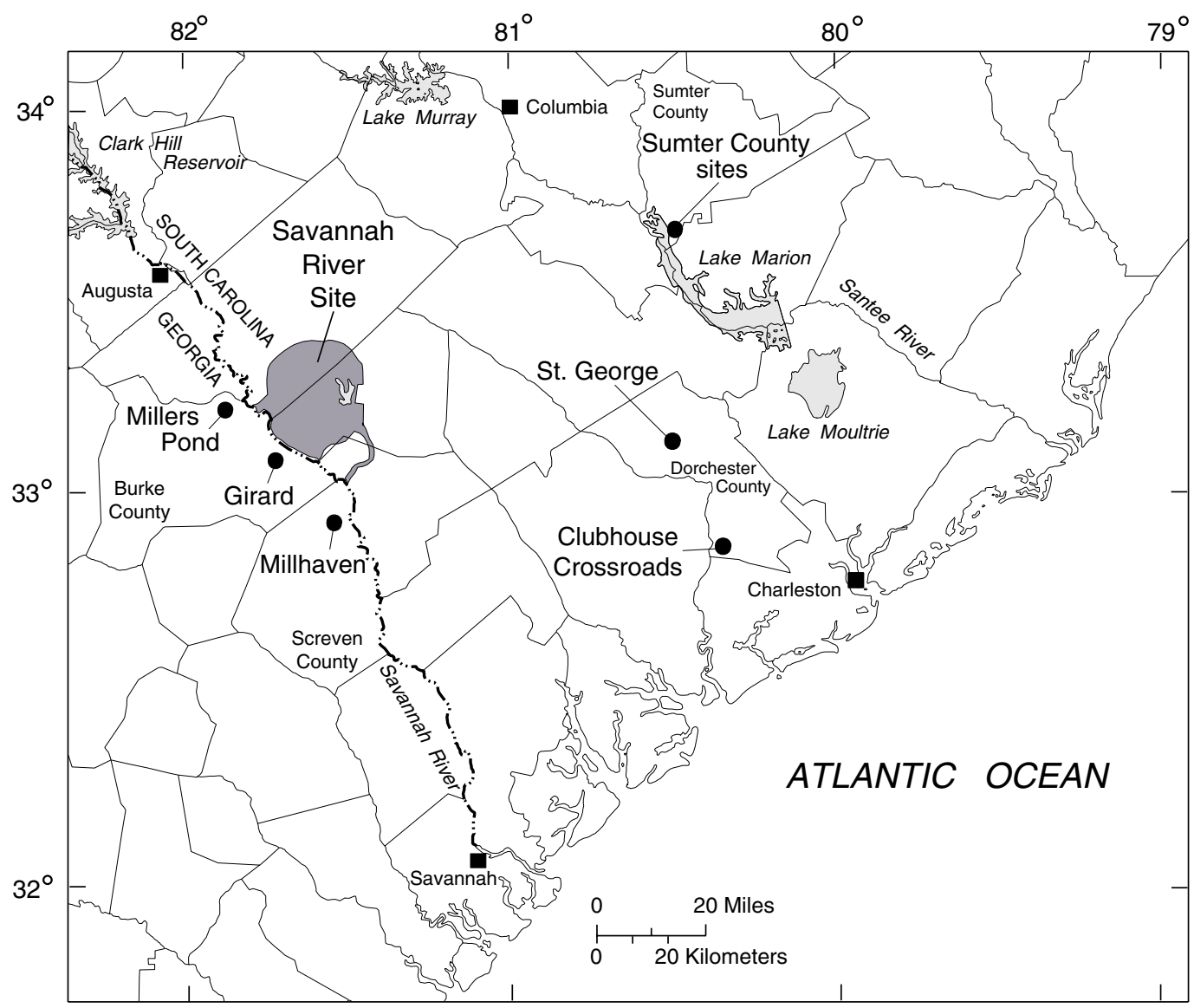

Figure 1. Location of the Millhaven test hole in Georgia and additional test holes in Georgia and South Carolina.

$1,452 \mathrm{ft}$ where the hole bottomed in the Upper Cretaceous Cape Fear Formation. This testhole is located in the Burtons Ferry Landing 7.5-minute quadrangle in northern Screven County at latitude $32^{\circ} 53^{\prime} 25^{\prime \prime}$ N., longitude $81^{\circ} 35^{\prime} 43^{\prime \prime} \mathrm{W}$. (fig. 1). Ground elevation at the drill site is $+110 \mathrm{ft}$. The lithologies and stratigraphy of the Millhaven section are discussed by Clarke and others (1996) and Falls and Prowell (this volume, chap. A).

Depths measured to specific horizons in the Millhaven core typically are 5 to $7 \mathrm{ft}$ deeper than the depths measured to the corresponding positions on the geophysical logs. In this report, and throughout this volume, core depths are used as the primary depth reference for samples and stratigraphic features. On figure 2, the geophysical logs for the Millhaven test hole have been shifted graphically (down $5 \mathrm{ft}$ ) to produce a closer correspondence between log depths and core depths.

\section{ACKNOWLEDGMENTS}

The site description of the Millhaven core by W. Fred Falls (USGS) was an important guide to this study of the
Millhaven Cretaceous section. USGS Volunteer-for-Science Xenedee Bradley assisted in the preparation of the ostracode samples from the Millhaven core. I thank Jean M. Self-Trail (USGS) for discussions of Cretaceous calcareous nannofossils in the South Carolina cores. Reviews by Harry Dowsett (USGS), Raymond Christopher (Clemson University), and Lucy Edwards (USGS) substantially improved the manuscript.

\section{CAMPANIAN MARINE DEPOSITS IN THE MILLHAVEN CORE}

\section{PHYSICAL STRATIGRAPHY}

Upper Cretaceous sediments are present in the Millhaven core between its base and a depth of $642 \mathrm{ft}$ (fig. 2) (Falls and others, 1997; Falls and Prowell, this volume, chap. A; Edwards and others, this volume, chap. B). Falls and Prowell (this volume, chap. A) assign the interval between 1,172 and $839 \mathrm{ft}$ to the Black Creek Group, which they divide into informal lithologic subunits 1,2 , and 3 


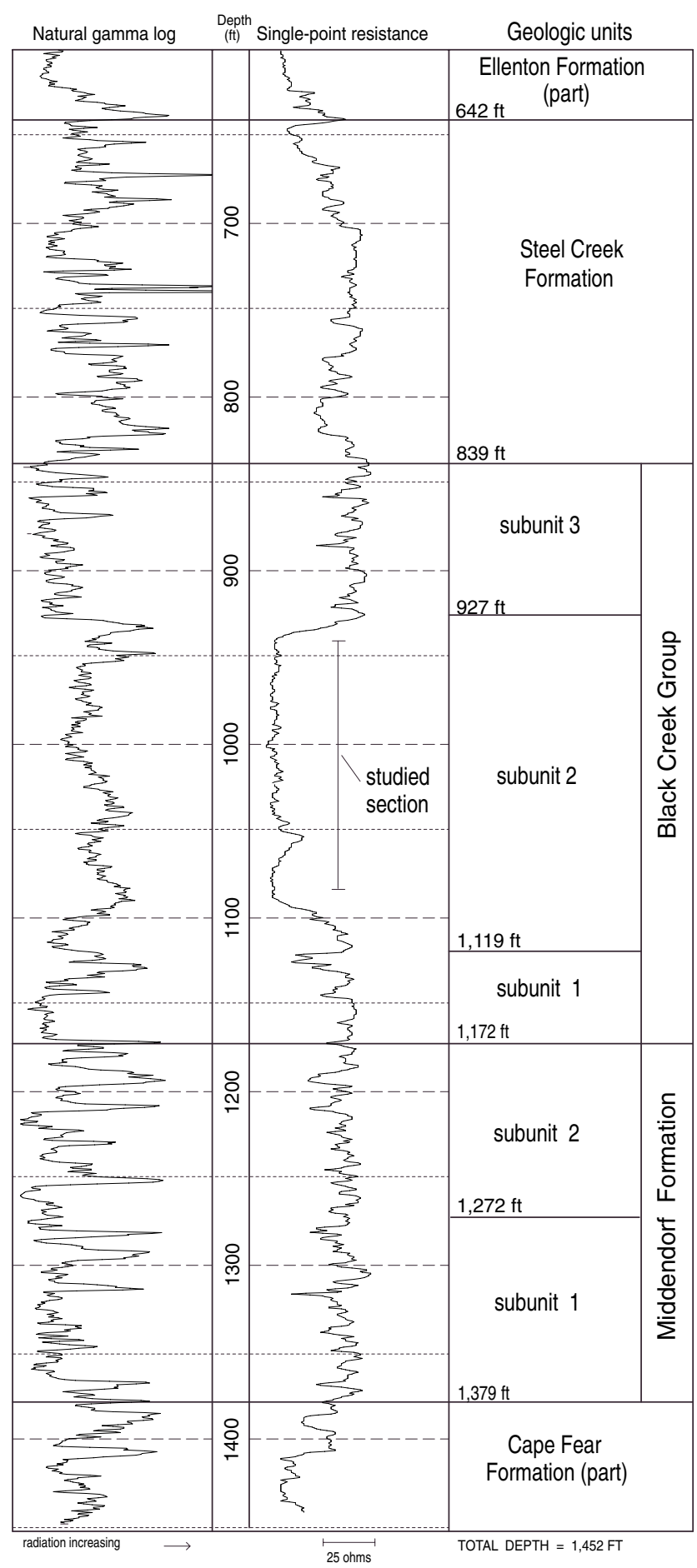

Figure 2. Geophysical logs and geologic units of the Cretaceous section in the Millhaven core to a depth of 1,452 feet. The stratigraphic position of Black Creek subunit 2, which was studied for this report, is indicated. The lithostratigraphy is from Falls and Prowell (this volume, chap. A). The geophysical logs have been shifted graphically to produce a correspondence between core depths and log depths for stratigraphic horizons. (from base to top). Black Creek subunit 2 (1,119 to $927 \mathrm{ft}$ ) contains the only calcareous Cretaceous sediments in the Millhaven core. The calcareous section is present between 1,085 and $940 \mathrm{ft}$ in the core.

From its basal contact at $1,119 \mathrm{ft}$ to $1,085 \mathrm{ft}$, Black Creek subunit 2 consists of noncalcareous, slightly to moderately muddy, fine to medium, and medium to very coarse sand. This section of sand is broadly gradational upward into calcareous fine-grained deposits that are more typical of the unit. The grain size of the sand fraction and the sand/ (clay+silt) ratio decrease upward in this basal interval.

Above 1,085 ft, Black Creek subunit 2 consists of sparingly calcareous to moderately calcareous, bioturbated, muddy, very fine to fine sand and similar appearing sandy and silty clay. Calcareous macrofossils, microfossils, and nannofossils are present from 1,085 to $965 \mathrm{ft}$ in subunit 2 . Molds of pelecypods, locally with traces of preserved calcium carbonate, are present above 965 to about $940 \mathrm{ft}$. An interval of slightly muddy, calcareous, very fine to fine sand is present from 1,063 to $1,051 \mathrm{ft}$. This sand has gradational contacts with underlying and overlying muddier sections. At the top of Black Creek subunit 2, its typically fine-grained deposits grade upward into moderately well-sorted, highly micaceous, very fine to fine sand (934 to $927 \mathrm{ft}$ ).

The dark, bioturbated, fine-grained sediments of Black Creek subunit 2 in the Millhaven core readily correlate with sections of similar fine-grained marine sediments that are included in the Black Creek Formation or Black Creek Group in wells throughout the Savannah River area (Logan and Euler, 1989; Fallaw and others, 1992a,b; Fallaw and Price, 1992, 1995; Falls and Prowell, this volume, chap. A). Despite their lithologic similarity to Black Creek subunit 2 at Millhaven, few of the correlative Black Creek marine sections have retained their calcareous fossils, probably owing to ground-water dissolution of the calcium carbonate.

\section{OSTRACODE BIOSTRATIGRAPHY}

\section{OSTRACODE SAMPLES}

Twenty-one ostracode samples were collected from the calcareous part of Black Creek subunit 2 in the Millhaven core between depths of $1,082.7$ and $940.0 \mathrm{ft}$. Of these, three samples at the top of the section $(965.5,956.0$, and $940.0 \mathrm{ft})$ did not produce a reaction when treated with dilute hydrochloric acid and were assumed to be noncalcareous; these samples were not processed.

The eighteen remaining samples were processed using standard microfossil techniques. Samples weighing approximately $150 \mathrm{~g}$ were soaked in deionized water and sieved. Ostracode valves and carapaces were picked from the fine, medium, and coarse sand fractions and placed on standard micropaleontology slides for sorting and identification. 
Table 1. Cretaceous ostracodes from the Black Creek Group in the Millhaven core, Screven County, Georgia.

[Samples are reported as depths (in $\mathrm{ft}$ ) below the surface]

\begin{tabular}{|c|c|c|c|c|c|c|c|c|c|c|c|c|c|c|c|}
\hline \multirow[b]{2}{*}{ Species } & \multicolumn{4}{|c|}{$\begin{array}{c}\text { Haplocytheridea } \\
\text { everetti assemblage }\end{array}$} & \multicolumn{9}{|c|}{ Haplocytheridea sarectaensis assemblage } & \multirow[b]{2}{*}{ Totals } & \multirow[b]{2}{*}{$\%$ of Total } \\
\hline & 1,043 & 1,038 & 1,033 & 1,029 & 1,021 & 1,015 & 1,010 & 1,005 & 1,000 & 995 & 989 & 985 & 975 & & \\
\hline Haplocytheridea sp. aff. H. everetti (Berry) -- & 0 & 0 & 0 & 0 & 222 & 253 & 11 & 44 & 15 & 31 & 0 & 57 & 0 & 633 & $42.9 \%$ \\
\hline Haplocytheridea sarectaensis Brown---------- & 0 & 0 & 0 & 0 & 30 & 24 & 8 & 3 & 0 & 4 & 1 & 109 & 16 & 195 & $13.2 \%$ \\
\hline Haplocytheridea renfroensis Crane -------- & 166 & 13 & 1 & 0 & 0 & 0 & 0 & 0 & 0 & 0 & 0 & 0 & 0 & 180 & $12.2 \%$ \\
\hline Haplocytheridea everetti (Berry)------------ & 30 & 21 & 63 & 5 & 0 & 0 & 0 & 0 & 0 & 0 & 0 & 0 & 0 & 119 & $8.1 \%$ \\
\hline Antibythocypris minuta (Berry) --- & 0 & 0 & 0 & 0 & 87 & 28 & 1 & 0 & 0 & 0 & 0 & 0 & 0 & 116 & $7.9 \%$ \\
\hline 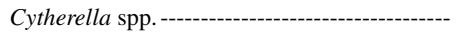 & 72 & 13 & 7 & 1 & 3 & 0 & 0 & 0 & 0 & 0 & 0 & 0 & 0 & 96 & $6.5 \%$ \\
\hline Brachycythere ovata (Berry) ------------ & 16 & 4 & 0 & 0 & 3 & 0 & 0 & 0 & 0 & 0 & 0 & 0 & 0 & 23 & $1.6 \%$ \\
\hline Eocytheropteron straillis Brown--- & 0 & 0 & 0 & 0 & 8 & 12 & 0 & 0 & 0 & 0 & 0 & 3 & 0 & 23 & $1.6 \%$ \\
\hline 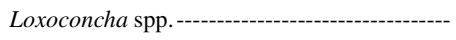 & 2 & 4 & 9 & 0 & 6 & 0 & 0 & 0 & 0 & 0 & 0 & 0 & 0 & 21 & $1.4 \%$ \\
\hline Brachycythere rhomboidalis (Berry) --------- & 0 & 0 & 0 & 0 & 16 & 4 & 0 & 0 & 0 & 0 & 0 & 0 & 0 & 20 & $1.4 \%$ \\
\hline Escharacytheridea pinochii (Jennings)------- & 16 & 0 & 0 & 0 & 0 & 0 & 0 & 0 & 0 & 0 & 0 & 0 & 0 & 16 & $1.1 \%$ \\
\hline Curfsina communis (Israelsky) ----------- & 5 & 0 & 1 & 0 & 4 & 0 & 0 & 0 & 0 & 0 & 0 & 0 & 0 & 10 & $0.7 \%$ \\
\hline Brachycythere spp. ------------------------ & 0 & 0 & 0 & 1 & 2 & 2 & 0 & 0 & 0 & 0 & 0 & 0 & 0 & 5 & $0.3 \%$ \\
\hline Fissocarinocythere pidgeoni (Berry) --------- & 1 & 0 & 0 & 0 & 2 & 2 & 0 & 0 & 0 & 0 & 0 & 0 & 0 & 5 & $0.3 \%$ \\
\hline Orthonotacythere hannai (Israelsky) --------- & 5 & 0 & 0 & 0 & 0 & 0 & 0 & 0 & 0 & 0 & 0 & 0 & 0 & 5 & $0.3 \%$ \\
\hline Cytheropteron(?) sp. - & 0 & 0 & 0 & 0 & 0 & 0 & 0 & 0 & 0 & 0 & 0 & 2 & 0 & 2 & $0.1 \%$ \\
\hline Orthonotacythere sulcata Brown------------ & 2 & 0 & 0 & 0 & 0 & 0 & 0 & 0 & 0 & 0 & 0 & 0 & 0 & 2 & $0.1 \%$ \\
\hline Antibythocypris fabaformis (Berry)---------- & 0 & 1 & 0 & 0 & 0 & 0 & 0 & 0 & 0 & 0 & 0 & 0 & 0 & 1 & $0.1 \%$ \\
\hline 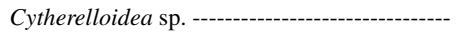 & 0 & 0 & 1 & 0 & 0 & 0 & 0 & 0 & 0 & 0 & 0 & 0 & 0 & 1 & $0.1 \%$ \\
\hline Paracypris(?) sp.----------------------------- & 0 & 0 & 0 & 0 & 0 & 1 & 0 & 0 & 0 & 0 & 0 & 0 & 0 & 1 & $0.1 \%$ \\
\hline Totals ---------------------------------------- & 315 & 56 & 82 & 7 & 383 & 326 & 20 & 47 & 15 & 35 & 1 & 171 & 16 & 1,474 & $100.0 \%$ \\
\hline
\end{tabular}

Five samples at the bottom of the section $(1,082.7$, $1,077.0,1,067.5,1,061.5$, and $1,051.5 \mathrm{ft}$ ) did not yield ostracodes upon processing. Planktonic foraminifers and mollusk fragments also are absent from these five samples; however, they do contain very sparse assemblages of calcareous benthic foraminifers, dominantly Lenticulina spp. The other thirteen samples produced very small to moderately large numbers of ostracode valves (table 1). These productive samples also contain mollusk fragments and calcareous and agglutinated benthic foraminifers. Variable abundances of planktonic foraminifers are present in some of these samples with heterohelicid genera dominating over globotruncanid genera except at 1,021 and $1,015 \mathrm{ft}$ where heterohelicids were not seen.

\section{OSTRACODE ASSEMBLAGES}

Two ostracode assemblages are present in Black Creek subunit 2 (table 1). The strong dominance of three taxa in each assemblage and the absence or near absence of these dominant forms in the other assemblage permit definition of the assemblages by inspection.

The lower assemblage, informally named the Haplocytheridea everetti (Berry) assemblage, is present in the four samples between the depths of 1,043 and 1,029 ft. The upper assemblage, informally named the Haplocytheridea sarectaensis Brown assemblage, is present in the nine samples between the depths of 1,021 and $975 \mathrm{ft}$.
The Haplocytheridea everetti (Berry) assemblage is dominated by the widely distributed species Haplocytheridea renfroensis Crane and Haplocytheridea everetti (Berry) as well as undescribed species of the genus Cytherella (table 1). These three taxa constitute about 85 percent of the recovered valves in this assemblage. Brachycythere ovata (Berry), Escharacytheridea pinochii (Jennings), and typically crushed or fragmented specimens of Loxoconcha spp. are the only other moderately common forms. Sparse described forms include Curfsina communis (Israelsky), Orthonotacythere hannai (Israelsky), Orthonotacythere sulcata Brown, Antibythocypris fabaformis (Berry), and Fissocarinocythere pidgeoni (Berry).

The Haplocytheridea sarectaensis Brown assemblage is dominated by Haplocytheridea sarectaensis Brown, Antibythocypris minuta (Berry), and an undescribed species assigned to Haplocytheridea sp. aff. H. everetti (Berry) (table 1). Together, these three species constitute about 93 percent of the assemblage. Sparse described forms include Eocytheropteron straillis Brown, Brachycythere rhomboidalis (Berry), Brachycythere ovata (Berry), Curfsina communis (Israelsky), and Fissocarinocythere pidgeoni (Berry).

\section{BIOSTRATIGRAPHY AND AGE}

Most of the described species in both Black Creek ostracode assemblages are long-ranging middle Campanian to Maastrichtian species or late Campanian to Maastrichtian species (Crane, 1965; Hazel and Brouwers, 1982; Gohn, 
1995). These long-ranging species include Antibythocypris fabaformis (Berry), Antibythocypris minuta (Berry), Brachycythere ovata (Berry), Brachycythere rhomboidalis (Berry), Haplocytheridea everetti (Berry), Haplocytheridea renfroensis Crane, Curfsina communis (Israelsky) and Orthonotacythere hannai (Israelsky).

Two of the described ostracode species in Black Creek subunit 2 can be used to place this section in the regional ostracode zonation of Hazel and Brouwers (1982), as modified by Pitakpaivan and Hazel (1994) (fig. 3). The presence of Escharacytheridea pinochii (Jennings) in the lowest studied sample (table 1), coupled with the presence of Fissocarinocythere pidgeoni (Berry) in higher samples, indicates placement of at least part of the studied section $(1,043$ to $1,015 \mathrm{ft})$ within the late Campanian to early Maastrichtian chronozones of the Escharacytheridea pinochii (Jennings) Interval Zone and (or) the Platycosta lixula (Crane) Interval Zone. This late Campanian to early Maastrichtian age is compatible with the late Campanian age assigned to the calcareous part of Black Creek subunit 2 at Millhaven by Bukry (this volume, chap. D) on the basis of calcareous nannofossils.

\section{PALEOENVIRONMENTS}

Species of the genera Haplocytheridea (Stephenson) and Antibythocypris (Jennings) tend to dominate the terrigenous inner-neritic deposits of the Atlantic and Gulf of Mexico Coastal Plains (Hazel and Brouwers, 1982; Puckett, 1996). Conversely, ornate trachyleberid forms and smooth-valved forms (except cytherellids) are more common in deeper water chalk and glauconite deposits and tend to be rare in shallow-marine deposits. In the Haplocytheridea everetti assemblage (table 1), Haplocytheridea specimens constitute about two-thirds of the recovered valves, and an inner-neritic paleoenvironment is inferred from this assemblage.

Similarly, in the Haplocytheridea sarectaensis Brown assemblage, the abundance of Haplocytheridea specimens and Antibythocypris minuta (Berry) in moderately diverse subassemblages at 1,021 and 1,015 ft suggests an inner-neritic paleoenvironment. The abundance of two Haplocytheridea species in the higher samples representing this assemblage and the paucity of other taxa suggest possible environmental restrictions during sedimentation in an inner-neritic paleoenvironment, perhaps a low-oxygen water column.

\section{DISCUSSION}

The relatively little-studied ostracode species Haplocytheridea sarectaensis Brown holds potential as a local biostratigraphic marker. Known occurrences of this species in eastern Georgia and South Carolina are limited to the

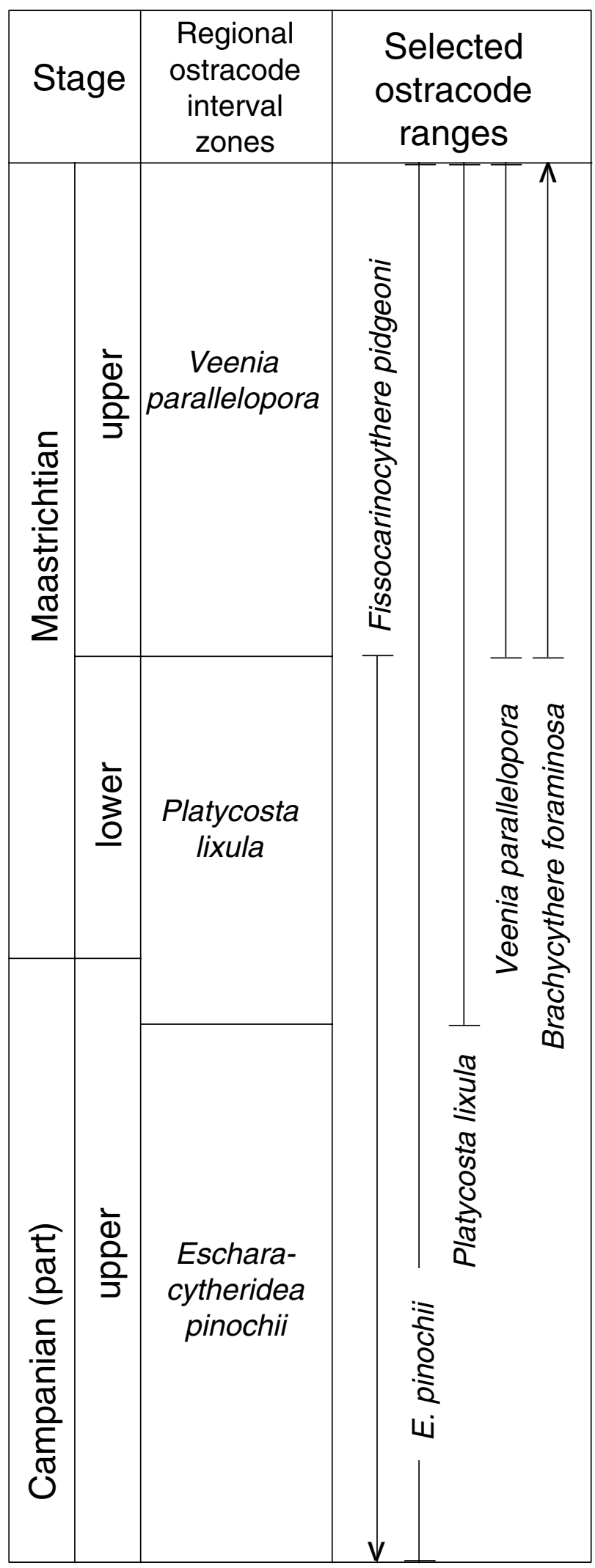

Figure 3. Ostracode interval zones and associated ostracode datums. The ostracode interval zones are from Hazel and Brouwers (1982) as modified by Pitakpaivan and Hazel (1994). 
upper part of calcareous nannofossil Zone CC 22. Haplocytheridea sarectaensis Brown is present in the interval assigned to Zone CC 22 in the Millhaven core (Bukry, this volume, chap. D) and in the USGS-St. George core in northern Dorchester County, central South Carolina (Self-Trail and Gohn, 1996; for locations, see fig. 1 of this chapter). I also have recorded $H$. sarectaensis Brown at 923 to $898 \mathrm{ft}$ in the USGS-Clubhouse Crossroads No. 1 core in southern Dorchester County, which is in a section representing calcareous nannofossil zone CC 22 (data in Hattner and Wise, 1980; J.M. Self-Trail, USGS, 1995, written commun.). In addition, some specimens from Sumter County, S.C., cores (fig. 1) that I previously assigned to Haplocytheridea wilmingtonensis Brown (in Prowell, 1993, p. 43) are assigned here to $H$. sarectaensis Brown. These occurrences of $H$. sarectaensis Brown in the Sumter County cores also are within calcareous nannofossil Zone CC 22 (J.M. Self-Trail, USGS, 1995, written commun.).

Burnett and others (1992), Bukry (1994; this volume, chap. D), and Burnett (1996) place the Campanian-Maastrichtian Stage boundary within calcareous nannofossil Subzone CC 23a shortly above the extinction level of Reinhardtites anthophorus (Deflandre) Perch-Nielsen at the top of Zone CC 22. Therefore, the upper part of calcareous nannofossil Zone CC 22 is very late Campanian, but not latest Campanian, in age. In eastern Georgia and South Carolina, the highest occurrence of Haplocytheridea sarectaensis Brown approximates the top of Zone CC 22 and, hence, approximates the position of the Campanian-Maastrichtian boundary.

The sections in central South Carolina containing Haplocytheridea sarectaensis Brown and calcareous nannofossil Zone CC 22 are assigned to the upper part of the Donoho Creek Formation of the Black Creek Group by Gohn (1992), Prowell (1993), and Self-Trail and Gohn (1996). Black Creek subunit 2 in the Millhaven core, therefore, occupies the same biostratigraphic position as the upper part of the Donoho Creek Formation in central South Carolina; it is also generally similar lithologically to the South Carolina Donoho Creek sections. As yet, however, Black Creek subunit 2 at Millhaven has not been traced lithologically through intervening drill holes to the central South Carolina sections. Although the Donoho Creek Formation is the uppermost formation in the Black Creek Group in central South Carolina (Gohn, 1992; Self-Trail and Gohn, 1996), the equivalent section is overlain by a substantial thickness of sediments assigned to the Black Creek subunit 3 in the Millhaven core (fig. 2) (Falls and Prowell, this volume, chap. A; Frederiksen and others, this volume, chap. C).

\section{TAXONOMIC NOTES ON OSTRACODES}

Most of the described ostracode species listed in table 1 are common, widespread forms that are adequately illus- trated in the literature. Except for a few selected taxa, these common species are not illustrated in this report; however, synonymies are provided as a guide to my concepts of these taxa. Brouwers and Hazel (1978) discussed many of the species listed in these notes; their detailed synonymies provide the bases for many of the synonymies used here. Undescribed species listed in table 1 are represented by small numbers of valves and are not treated in these notes; the several species representing the smooth-valved genus Cytherella Jones also are not treated. Listed stratigraphic ranges are from Hazel and Brouwers (1982) unless otherwise stated.

\section{ANTIBYTHOCYPRIS FABAFORMIS (BERRY, 1925)}

Cytherella fabaformis Berry, 1925, p. 487, fig. 13.

Cytheridea fabaformis (Berry, 1925). Alexander, 1929, p. 76, pl. 5, fig. 18.

Haplocytheridea? fabaformis (Berry, 1925). Schmidt, 1948, p. 426 , pl. 62 , fig. 23 , text-fig. 2e; Howe and Laurencich, 1958, p. 350, text-fig.; Benson and Tatro, 1964, p. 16, pl. 3, fig. 13; Crane, 1965 , p. 199 , pl. 1, fig. $11 A, B$; Van Nieuwenhuise and Kanes, 1976, pl. 3, fig. $B$.

Cytheridea (Haplocytheridea) fabaformis (Berry, 1925). Brown, 1957, p. 17, pl. 2, figs. 7, 8; Brown, 1958, p. 58, pl. 5 , fig. 7.

Antibythocypris fabaformis (Berry, 1925). Brouwers and Hazel, 1978, p. 25, pl. 2, fig. 8; pl. 3, figs. 1-3; pl. 10, fig. 5; Hazel and Brouwers, 1982, p. 181, pl. 5, fig. 3; Gohn, 1995, pl. II, fig. 9.

Cythere ulrichi Berry, 1925, p. 483, fig. 3.

Stratigraphic range.-Middle Campanian through Maastrichtian.

\section{ANTIBYTHOCYPRIS MINUTA (BERRY, 1925)}

Plate 1, figure 3

Cytherideis minutus Berry, 1925, p. 487, fig. 12.

Cytherideis minuta Berry, 1925. Howe and Laurencich, 1958, p. 286.

Antibythocypris minuta (Berry, 1925). Brouwers and Hazel, 1978, p. 25, pl. 3, figs. 4-7; pl. 10, fig. 6; Hazel and Brouwers, 1982, p. 184, pl. 4, fig. 2; pl. 5, fig. 13; Gohn, 1995, pl. II, fig. 11.

Haplocytheridea? ulrichi (Berry, 1925). Schmidt, 1948, p. 426, pl. 62, figs. 18, 19; Howe and Laurencich, 1958, p. 358, text-fig.; Crane, 1965, p. 200, pl. 1, fig. 9A, B.

Cytheridea (Haplocytheridea) ulrichi (Berry, 1925). Brown, 1957 , p. 18 , pl. 2, figs. 4 , 5; Brown, 1958 , p. 58, pl. 5 , fig. 6.

Haplocytheridea? macropora (Alexander, 1929). Schmidt, 1948 , p. 425 , pl. 62, fig. 24; Van Nieuwenhuise and Kanes, 1976, pl. 4, fig. A. 
Remarks.-Cythere ulrichi Berry, 1925, is the female dimorph of Antibythocypris fabaformis (Berry, 1925). The similar species Antibythocypris macropora (Alexander, 1929) is common in the Gulf of Mexico Coastal Plain but is rare in the Atlantic Coastal Plain. Antibythocypris minuta typically occurs in inner-neritic muddy sands in South Carolina sections of the Black Creek Group and Peedee Formation (Self-Trail and Gohn, 1996).

Stratigraphic range.-Middle Campanian through Maastrichtian.

\section{BRACHYCYTHERE OVATA (BERRY, 1925)}

Cythereis ovatus Berry, 1925, p. 484, fig. 15.

Cythere ovata (Berry, 1925). Alexander, 1929, p. 87, pl. VII, figs. $10,13$.

Brachycythere ovata (Berry, 1925). Skinner, 1956, p. 190, pl. II, fig. 3A-C; Howe and Laurencich, 1958, p. 89, text-figs.; Benson and Tatro, 1964, p. 19, pl. 4, figs. 1113, text-fig. 6; Crane, 1965 , p. 210 , pl. 4, fig. $1 A, B$; Brouwers and Hazel, 1978, pl. 7, figs. 5-7, pl. 11, fig. 4; Hazel and Brouwers, 1982, p. 185, pl. 4, fig. 12; Pitakpaivan and Hazel, 1994, fig. 3-(2); Gohn, 1995, pl. II, fig. 2.

Brachycythere ovata vecarina Crane, 1965, p. 210, pl. 4, fig. $3 A, B$.

Cytheropteron sp. A, Israelsky, 1929, p. 7, pl. IA, fig. 1A, C. Stratigraphic range.-Upper Campanian through Maastrichtian.

\section{BRACHYCYTHERE RHOMBOIDALIS (BERRY, 1925)}

Cythere rhomboidalis Berry, 1925, p. 481, figs. 1, 2.

Cythere rhomboidalis Berry, 1925. Alexander, 1929, p. 86, pl. VII, figs. 1, 2.

Brachycythere rhomboidalis (Berry, 1925). Schmidt, 1948, p. 414, pl. 62, figs. 8-10; Butler and Jones, 1957, p. 28, pl. 3, fig. 2A, B; Brown, 1957, p. 11, pl. 4, figs. 5, 8-10; Brown, 1958, p. 61, pl. 2, fig. 9; Howe and Laurencich, 1958, p. 90, text-figs.; Benson and Tatro, 1964, p. 19, pl. 5, figs. 16-18, text-fig. 7; Crane, 1965, p. 209, pl. 4, fig. 7; Van Nieuwenhuise and Kanes, 1976, pl. 2, fig. $C$; Brouwers and Hazel, 1978, pl. 7, fig. 8; pl. 8, figs. 1-3; pl. 11, fig. 5; Smith, 1978, p. 551, pl. 4, figs. 4-6, 10; Hazel and Brouwers, 1982, p. 189, pl. 4, fig. 6; Pitakpaivan and Hazel, 1994, fig. 3-(3); Gohn, 1995, pl. II, fig. 1.

Brachycythere jerseyensis Jennings, 1936, p. 48, pl. 6, fig. $14 A, B$.

Remarks.-Specimens assigned to Pterygocythere pinguita Crane, 1965 by Crane (1965) and Smith (1978) probably represent Brachycythere rhomboidalis (Berry, 1925).

Stratigraphic range.-Upper Campanian through Maastrichtian.
CURFSINA COMMUNIS (ISRAELSKY, 1929)

Cythereis communis Israelsky, 1929, p. 14, pl. 3A, figs. 913.

Cythereis communis Israelsky, 1929. Alexander, 1929, p. 101, pl. IX, fig. 18; Jennings, 1936, p. 52, pl. 7, fig. 3; Schmidt, 1948, p. 419, pl. 61, figs. 11-13; Skinner, 1956, p. 196, pl. III, fig. 7A-E; Butler and Jones, 1957, p. 35, pl. 3, fig. 6; Howe and Laurencich, 1958, p. 189, text-fig; Crane, 1965 , p. 221, pl. 6, fig. 12; Van Nieuwenhuise and Kanes, 1976, pl. 2, figs. A, B; Brouwers and Hazel, 1978, pl. 5, figs. 7-9; pl. 10, fig. 8; Smith, 1978, p. 554, pl. 5, figs. 20-23.

Trachyleberis communis (Israelsky, 1929). Brown, 1957, p. 14, pl. 3, figs. 10, 11; Brown, 1958, p. 63, pl. 4, fig. 5.

Trachyleberis? communis (Israelsky, 1929). Benson and Tatro, 1964, p. 22, pl. 5, figs. 13-15, text-fig. 10.

Curfsina communis (Israelsky, 1929). Hazel and Brouwers, 1982 , p. 180, pl. 1, fig. 12; Pitakpaivan and Hazel, 1994, fig. 3-(4); Gohn, 1995, pl. I, fig. 5.

Paracythereis semilenis Schmidt, 1948, p. 418, pl. 61, fig. 14.

Remarks.-Paracythereis semilenis Schmidt, 1948, is a molt of Curfsina communis (Israelsky, 1929).

Stratigraphic range.-Middle Campanian through Maastrichtian.

\section{EOCYTHEROPTERON STRAILLIS BROWN, 1957}

Plate 1, figure 6

Cytheropteron (Eocytheropteron) straillis Brown, 1957, p. 20, pl. 6, figs. 14, 15.

Cytheropteron (Eocytheropteron) straillis Brown, 1957. Brown, 1958, p. 60, pl. 7, fig. 14.

Stratigraphic range.-Upper Campanian-Maastrichtian (data in Brown, 1957; this report).

\section{ESCHARACYTHERIDEA PINOCHII (JENNINGS, 1936)}

Plate 1, figure 5

Cytheridea pinochii Jennings, 1936, p. 58, pl. 7, fig. 9.

Haplocytheridea? pinochii (Jennings, 1936). Howe and Laurencich, 1958, p. 356, text-fig.

Escharacytheridea pinochii (Jennings, 1936). Hazel and Brouwers, 1982, p. 185, pl. 5, fig. 9; pl. 6, fig. 13; Gohn, 1995, pl. III, fig. 1; Puckett, 1995, p. 25, pl. 1, figs. 13, 14.

Remarks.-Marker species for the base of the Escharacytheridea pinochii Interval Zone of Hazel and Brouwers (1982).

Stratigraphic range.-Upper Campanian and Maastrichtian.

\section{FISSOCARINOCYTHERE PIDGEONI (BERRY, 1925)}

Cytheridea pidgeoni Berry, 1925, p. 485, figs. 7, 8. 
Cythereis pidgeoni (Berry, 1925). Schmidt, 1948, p. 421, pl. 62, figs. 2-6; Howe and Laurencich, 1958, p. 223, text-figs.; Crane, 1965 , p. 216, pl. 5, fig. $10 A, B$; Van Nieuwenhuise and Kanes, 1976, p. 87, pl. 4, fig. $B$.

Trachyleberis pidgeoni (Berry, 1925). Brown, 1957, p. 14, pl. 7, figs. 26, 27; Brown, 1958, p. 63, pl. 4, fig. 3; Benson and Tatro, 1964, p. 22, pl. 5, figs. 1-3, text-fig. 11.

Fissocarinocythere pidgeoni (Berry, 1925). Brouwers and Hazel, 1978, p. 40, pl. 7, figs. 1-4; pl. 11, fig. 3; Hazel and Brouwers, 1982, p. 185, pl. 1, fig. 14.

“Archicythereis” cf. Cythereis pidgeoni (Berry, 1925). Schmidt, 1948, p. 417, pl. 62, fig. 1.

Remarks._- “Archicythereis” cf. Cythereis pidgeoni (Berry, 1925) of Schmidt (1948) is a molt of Fissocarinocythere pidgeoni (Berry, 1925). Marker species for the top of the Platycosta lixula Interval Zone of Pitakpaivan and Hazel (1994).

Stratigraphic range.-Upper Campanian and lower Maastrichtian (Hazel and Brouwers, 1982; Pitakpaivan and Hazel, 1994).

\section{HAPLOCYTHERIDEA EVERETTI (BERRY, 1925)}

Cytheridea everetti Berry, 1925, p. 486, fig. 9.

Cytheridea everetti Berry, 1925. Alexander, 1929, p. 74, pl. 5, figs. 9, 10 .

Haplocytheridea? everetti (Berry, 1925). Howe and Laurencich, 1958, p. 350, text-fig.

Haplocytheridea everetti (Berry, 1925). Brouwers and Hazel, 1978, p. 17, pl. 1, figs. 4, 6, 7, 9; pl. 10, fig. 3; Smith, 1978, p. 550, pl. 2, fig. 18; Hazel and Brouwers, 1982, p. 181, pl. 5, fig. 8; Puckett, 1992, pl. 2, fig. 14.

Cytheridea monmouthensis Berry, 1925, p. 486, fig. 10.

Cytheridea (Haplocytheridea) monmouthensis (Berry, 1925). Brown, 1957, p. 19, pl. 2, fig. 6; Brown, 1958, p. 58, pl. 5, fig. 11 .

Haplocytheridea monmouthensis (Berry, 1925). Benson and Tatro, 1964, p. 16, pl. 6, figs. 17, 21, 23.

Cytheridea truncatus Berry, 1925, p. 485, fig. 6.

Haplocytheridea plummeri (Alexander, 1929). Schmidt, 1948 , p. 425 , pl. 62 , figs. 27-29.

Cytheridea (Haplocytheridea) plummeri Alexander, 1929. Brown, 1957, p. 18, pl. 2, figs. 9-11.

Cytheridea (Haplocytheridea) punctura (Schmidt, 1948). Brown, 1957, p. 19, pl. 2, figs. 26-28; Brown, 1958, pl. 5, fig. 11 .

Remarks.-Cytheridea truncatus Berry, 1925 is a juvenile of Haplocytheridea everetti (Berry, 1925).

Stratigraphic range.-Middle Campanian through Maastrichtian.

\section{HAPLOCYTHERIDEA RENFROENSIS CRANE, 1965}

Haplocytheridea? renfroensis Crane, 1965, p. 201, pl. 2, fig. $1 A, B$.

Haplocytheridea renfroensis Crane, 1965. Brouwers and Hazel, 1978, p. 18, pl. 1, fig. 8; pl. 2, figs. 1, 2; pl. 10, fig. 4; Hazel and Brouwers, 1982, p. 189, pl. 4, fig. 17; pl. 5, fig. 11; Pitakpaivan and Hazel, 1994, fig. 5-(4).

Cytheridea monmouthensis Berry, 1925. Alexander, 1929, p. 74, pl. 5, figs. 11-14.

Haplocytheridea monmouthensis (Berry, 1925). Swain, 1952 , p. 79, pl. 18, fig. 19; Howe and Laurencich, 1958, p. 355 , text-fig.

Haplocytheridea? sp. cf. H. monmouthensis (Berry, 1925). Crane, 1965, p. 200, pl. 1, fig. $12 A, B$.

Haplocytheridea? monmouthensis (Berry, 1925). Smith, 1978, p. 550, pl. 2, figs. 14-16.

Haplocytheridea pinochii (Jennings, 1936). Schmidt, 1948, p. 427, pl. 61, figs. 25, 26.

Cytheridea plummeri Alexander, 1929. Skinner, 1956, p. 197, pl. 4, fig. $2 A, D$.

Haplocytheridea? plummeri (Alexander, 1929). Butler and Jones, 1957, p. 16, pl. 4, fig. 9; Benson and Tatro, 1964, p. 16 , pl. 3 , figs. $25-27$.

Stratigraphic range.-Middle Campanian through Maastrichtian.

\section{HAPLOCYTHERIDEA SARECTAENSIS BROWN, 1957}

Plate 1, figures 1,2

Cytheridea (Haplocytheridea) sarectaensis, Brown, 1957, p. 17, pl. 7, figs. 1-3.

Description.-Sexual dimorphism is pronounced. Females have a rounded subtriangular outline and are flattened ventrally; the dorsal margin is broadly convex and slightly angled in front of mid-length; the ventral margin is straight in right valves, slightly sinuous in left. Males have elongate-subquadrate outlines; the dorsal margin is very broadly convex; the ventral margin is straight in right valves, slightly sinuous in left. The central three-quarters of the lateral surface has prominent smooth, low, subvertical ridges that alternate with pitted subvertical furrows. The longest furrow is slightly in front of the mid-length and is convex toward the anterior; the marginal areas of the lateral surfaces are smooth. A low node is present near the posterior-ventral termination in right valves. An indistinct, vertically elongate node near the anterior margin causes the lateral surface to descend steeply to the slanting anterior margin; this node is most pronounced in right valves. The valves have a narrow duplicature and a shallow anterior vestibule. The valves have a holomerodont hinge, the anterior hinge element is distinctly larger than the posterior element, and the medial element is narrow. Muscle scars are not discerned. 
Measurements.-Below are measurements (in millimeters) of 16 female and 6 male specimens:

\begin{tabular}{|c|c|c|c|}
\hline & Number & Average & $\begin{array}{c}\text { Observed } \\
\text { range }\end{array}$ \\
\hline \multicolumn{4}{|l|}{ Female: } \\
\hline Length ---------- & 16 & 0.63 & $0.58-0.67$ \\
\hline Height & 16 & 0.36 & $0.33-0.45$ \\
\hline \multicolumn{4}{|l|}{ Male: } \\
\hline Length ------- & 6 & 0.75 & $0.72-0.78$ \\
\hline Height & 6 & 0.40 & $0.37-0.43$ \\
\hline
\end{tabular}

Comparisons.-The smaller size, pronounced dimorphism, and vertical ridges and furrows of Haplocytheridea sarectaensis Brown readily distinguish this species from Haplocytheridea everetti (Berry) and Haplocytheridea renfroensis Crane.

Remarks.-As noted by Brown (1957), this species closely resembles early Tertiary species that were later assigned by Hazel (1968) to the genus Phractocytheridea Sutton and Williams. In fact, Hazel (1968, p. 131) included Haplocytheridea sarectaensis Brown in Phractocytheridea Sutton and Williams. However, the Millhaven specimens appear to lack the strong shelf at the bottom of the anterior socket (left-valve hinge) that was deemed characteristic of Phractocytheridea Sutton and Williams by Hazel (1968). Therefore, this species is left in Haplocytheridea Stephenson in this report. At least one of the specimens assigned to Phractocytheridea cf. P. sarectaensis (Brown, 1957) by Puckett (1996, pl. 2, fig. 4) represents the related, more rugose species Haplocytheridea wilmingtonensis Brown.

Stratigraphic range.-Upper Campanian (data in Brown, 1957; Self-Trail and Gohn, 1996; Gohn, this report).

\section{HAPLOCYTHERIDEA SP. AFF. HAPLOCYTHERIDEA EVERETTI (BERRY, 1925)}

Plate 1, figure 4

Description.-Valves are moderate sized and subtriangular; males are slightly longer than females. The dorsal margin is slightly angled in females; the ventral margin is sinuous in left valves and straight in right valves. The anterior margin is broadly rounded and denticulate; denticles are more abundant on the right valve; the posterior margin is rounded and extended. The posterior fifth of the ventral margin is denticulate in the right valve. Node-like thickenings of the left valve occur at the center of the anterior margin and at the posterior termination; this thickening is most pronounced in females. The central two-thirds of the lateral surface has moderate-sized pits; two short, smooth vertical ridges at the center are separated and flanked by shallow, pitted furrows. In right valves, the lateral surface descends at a steep angle to the anterior margin, producing a blunt anterior termination. The anterior vestibule is shallow; the hinge is holomerodont.
Stratigraphic range.-Middle and upper Campanian (Gohn, this report; G. Gohn, unpub. data).

\section{ORTHONOTACYTHERE HANNAI (ISRAELSKY, 1929)}

Cytheridea? hannai Israelsky, 1929, p. 12, pl. 2A, fig. $10 A, B$.

Cytheropteron hannai (Israelsky, 1929). Alexander, 1929, p. 105, pl. IX, fig. 16.

Orthonotacythere hannai (Israelsky, 1929). Alexander, 1933 , p. 200 , pl. 25 , fig. $1 A-C$; pl. 26 , fig. $6 A, B$; pl. 27 , fig. $14 A$, $B$; Skinner, 1956, p. 202, pl. IV, fig. $9 A, B$; Butler and Jones, 1957, p. 21, pl. 4, fig. 2; Brown, 1957, p. 24, pl. 6, figs. 3-5; Brown, 1958, p. 67, pl. 4, fig. 13; Howe and Laurencich, 1958, p. 436, text-figs.; Crane, 1965 , p. 207, pl. 8, fig. 24; Brouwers and Hazel, 1978, pl. 9, fig. 4; Smith, 1978, p. 551, pl. 3, fig. 13; Hazel and Brouwers, 1982, p. 184, pl. 3, fig. 6; Pitakpaivan and Hazel, 1994, fig. 5-(8).

Orthonotacythere (Orthonotacythere) hannai (Israelsky, 1929). Benson and Tatro, 1964, p. 27, pl. 6, figs. 6, 7.

Stratigraphic range.-Upper Campanian and Maastrichtian (Crane, 1965; Puckett, 1996).

\section{ORTHONOTACYTHERE SULCATA BROWN, 1957}

Orthonotacythere sulcata Brown, 1957, p. 23, pl. 6, figs. 68.

Orthonotacythere sulcata Brown, 1957. Brown, 1958, p. 68, pl. 4 , fig. 14.

Remarks.-This species may be equivalent to Orthonotacythere scrobiculata Alexander (Alexander, 1934).

Stratigraphic range.-Campanian (data in Brown, 1957, 1958; Self-Trail and Gohn, 1996).

\section{REFERENCES CITED}

Alexander, C.I., 1929, Ostracoda of the Cretaceous of north Texas: University of Texas Bulletin 2907, 137 p.

1933, Shell structure of the ostracode Genus Cytheropteron, and fossil species from the Cretaceous of Texas: Journal of Paleontology, v. 7, no. 2, p. 181-214.

1934, Ostracoda of the genera Monoceratina and Orthonotacythere from the Cretaceous of Texas: Journal of Paleontology, v. 8, no. 1, p. 57-67.

Benson, R.H., and Tatro, J.O., 1964, Faunal description of Ostracoda of the Marlbrook Marl (Campanian), Arkansas: The University of Kansas Paleontological Contributions, Article 7, 32 p.

Berry, E.W., 1925, Upper Cretaceous Ostracoda from Maryland: American Journal of Science, v. 9, p. 481-487.

Brouwers, E.M., and Hazel, J.E., 1978, Ostracoda and correlation of the Severn Formation (Navarroan; Maestrichtian) of Maryland: Society of Economic Paleontologists and Mineralogists Paleontological Monograph No. 1 (Journal of Paleontology, v. 52, no. 6, suppl.), 52 p. 
Brown, P.M., 1957, Upper Cretaceous Ostracoda from North Carolina: North Carolina Division of Mineral Resources Bulletin $70,29 \mathrm{p}$.

1958, Well logs from the Coastal Plain of North Carolina: North Carolina Division of Mineral Resources Bulletin 72, $68 \mathrm{p}$.

Bukry, David, 1994, Coccolith correlation of Late Cretaceous Point Loma Formation at La Jolla and Carlsbad, San Diego County, California: U.S. Geological Survey Open-File Report 94-678, $23 \mathrm{p}$.

Burnett, J.A., 1996, Nannofossils and Upper Cretaceous (sub-) stage boundaries-State of the art: Journal of Nannoplankton Research, v. 18, no. 1, p. 23-32.

Burnett, J.A., Hancock, J.M., Kennedy, W.J., and Lord, A.R., 1992, Macrofossil, planktonic foraminiferal and nannofossil zonation at the Campanian/Maastrichtian boundary: Newsletters on Stratigraphy, v. 27 , no. 3, p. 157-172.

Butler, E.A., and Jones, D.E., 1957, Cretaceous Ostracoda of Prothro and Rayburns salt domes, Bienville Parish, Louisiana: Louisiana Geological Survey Geological Bulletin 32, 62 p.

Clarke, J.S., 1992, Evaluation of ground-water flow and quality in the vicinity of the Savannah River Site, Georgia and South Carolina [abs.]: Geological Society of America Abstracts with Programs, v. 24, no. 2, p. 9.

1995, Ground-water flow study in the vicinity of the Savannah River Site, South Carolina and Georgia: U.S. Geological Survey Fact Sheet FS-178-95, 5 p.

Clarke, J.S., Falls, W.F., Edwards, L.E., [Bukry, David,] Frederiksen, N.O., Bybell, L.M., Gibson, T.G., Gohn, G.S., and Fleming, Farley, 1996, Hydrogeologic data and aquifer interconnection in a multi-aquifer system in coastal plain sediments near Millhaven, Screven County, Georgia, 1991-95: Georgia Geologic Survey Information Circular 99, 43 p., 1 pl. in pocket.

Clarke, J.S., Falls, W.F., Edwards, L.E., Frederiksen, N.O., Bybell, L.M., Gibson, T.G., and Litwin, R.J., 1994 [1995], Geologic, hydrologic and water-quality data for a multi-aquifer system in coastal plain sediments near Millers Pond, Burke County, Georgia, 1992-93: Georgia Geologic Survey Information Circular 96, 34 p., 1 pl. in pocket.

Crane, M.J., 1965, Upper Cretaceous ostracodes of the Gulf Coast area: Micropaleontology, v. 11, no. 2, p. 191-254.

Fallaw, W.C., and Price, Van, 1992, Outline of stratigraphy at the Savannah River Site, in Fallaw, Wallace, and Price, Van, eds., Geological investigations of the central Savannah River area, South Carolina and Georgia: Carolina Geological Society Field Trip Guidebook 1992, November 13-15, 1992, Augusta, Georgia, p. B-II-1 to B-II-33.

1995, Stratigraphy of the Savannah River Site and vicinity: Southeastern Geology, v. 35, no. 1, p. 21-58.

Fallaw, W.C., Price, Van, and Thayer, P.A., 1992a, Cretaceous lithofacies at the Savannah River Site, South Carolina, in Zullo, V.A., Harris, W.B., and Price, Van, eds., Savannah River Region: Transition between the Gulf and Atlantic Coastal Plains: Proceedings of the Second Bald Head Island Conference on Coastal Plains Geology, Hilton Head Island, November 6-11, 1990, University of North Carolina at Wilmington, p. 50-51.

1992b, Stratigraphy of the Savannah River Site, South Carolina, in Zullo, V.A., Harris, W.B., and Price, Van, eds.,
Savannah River Region: Transition between the Gulf and Atlantic Coastal Plains: Proceedings of the Second Bald Head Island Conference on Coastal Plains Geology, Hilton Head Island, November 6-11, 1990, University of North Carolina at Wilmington, p. 29-32.

Falls, W.F., Baum, J.S., and Prowell, D.C., 1997, Physical stratigraphy and hydrostratigraphy of Upper Cretaceous and Paleocene sediments, Burke and Screven Counties, Georgia: Southeastern Geology, v. 36, no. 4, p. 153-176.

Gohn, G.S., 1992, Revised nomenclature, definitions, and correlations for the Cretaceous formations in USGS-Clubhouse Crossroads \#1, Dorchester County, South Carolina: U.S. Geological Survey Professional Paper 1518, 39 p, 1 pl. in pocket.

1995, Ostracode biostratigraphy of the Upper Cretaceous marine sediments in the New Jersey Coastal Plain, in Baker, J.E.B., ed., Contributions to the paleontology of New Jersey: Geological Association of New Jersey Contribution Proceedings, v. 12, p. 87-101.

Hattner, J.G., and Wise, S.W., Jr., 1980, Upper Cretaceous calcareous nannofossil biostratigraphy of South Carolina: South Carolina Geology, v. 24, no. 2, p. 41-117.

Hazel, J.E., 1968, Ostracodes from the Brightseat Formation (Danian) of Maryland: Journal of Paleontology, v. 42, no. 1, p. 100-142.

Hazel, J.E., and Brouwers, E.M., 1982, Biostratigraphic and chronostratigraphic distribution of ostracodes in the Coniacian-Maastrichtian (Austinian-Navarroan) in the Atlantic and Gulf Coastal Province, in Maddocks, R.F., ed., Texas Ostracoda, Guidebook of excursions and related papers for the Eighth International Symposium on Ostracoda: Houston, University of Houston, p. 166-198.

Howe, H.V., and Laurencich, L., 1958, Introduction to the study of Cretaceous Ostracoda: Baton Rouge, Louisiana State University Press, $536 \mathrm{p}$.

Israelsky, M.C., 1929, Upper Cretaceous Ostracoda of Arkansas: Arkansas Geological Survey Bulletin 2, p. 3-29.

Jennings, P.H., 1936, A microfauna from the Monmouth and basal Rancocas Groups of New Jersey: Bulletins of American Paleontology, v. 23, no. 78, p. 1-76.

Leeth, D.C., Falls, W.F., Edwards, L.E., Frederiksen, N.O., and Fleming, R.F., 1996, Geologic, hydrologic, and water-chemistry data for a multi-aquifer system in coastal plain sediments near Girard, Burke County, Georgia, 1992-95: Georgia Geologic Survey Information Circular 100, 26 p., 1 pl. in pocket.

Logan, W.R., and Euler, G.M., 1989, Geology and ground-water resources of Allendale, Bamberg, and Barnwell Counties and part of Aiken County, South Carolina: South Carolina Water Resources Commission Report 155, 113 p.

Pitakpaivan, Kasana, and Hazel, J.E., 1994, Ostracodes and chronostratigraphic position of the Upper Cretaceous Arkadelphia Formation of Arkansas: Journal of Paleontology, v. 68, no. 1, p. 111-122.

Prowell, D.C., 1993, Late Cretaceous stratigraphy in the central Coastal Plain of South Carolina: New evidence from drill holes near Lake Marion, Sumter County: South Carolina Geology, v. 36, p. 35-46.

Puckett, T.M., 1992, Distribution of ostracodes in the Upper Cretaceous (late Santonian through middle Maastrichtian) of Alabama and Mississippi: Gulf Coast Association of Geological Societies Transactions, v. 42, p. 613-631. 
1995, Planktonic foraminiferal and ostracode biostratigraphy of the late Santonian through early Maastrichtian strata in Dallas County, Alabama: Geological Survey of Alabama Bulletin $164,59 \mathrm{p}$.

1996, Ecologic atlas of Upper Cretaceous ostracodes of Alabama: Geological Survey of Alabama Monograph 14, $176 \mathrm{p}$.

Schmidt, R.A.M., 1948, Ostracoda from the Upper Cretaceous and lower Eocene of Maryland, Delaware, and Virginia: Journal of Paleontology, v. 22, no. 4, p. 389-431.

Self-Trail, J.M., and Gohn, G.S., 1996, Biostratigraphic data for the Cretaceous marine sediments in the USGS-St. George No. 1 core (DOR-211), Dorchester County, South Carolina: U.S. Geological Survey Open-File Report 96-684, 29 p.
Skinner, H.C., 1956, Ostracoda from basal Arkadelphia Marl exposures near Hope, Arkansas: Gulf Coast Association of Geological Societies Transactions, v. 6, p. 179-204.

Smith, J.K., 1978, Ostracoda of the Prairie Bluff Chalk, Upper Cretaceous, (Maestrichtian) and the Pine Barren Member of the Clayton Formation, lower Paleocene, (Danian) from exposures along Alabama state highway 263 in Lowndes County, Alabama: Gulf Coast Association of Geological Societies Transactions, v. 28, p. 539-579.

Swain, F.M., 1952, Part 2, Mesozoic Ostracoda, chap. B of Ostracoda from wells in North Carolina: U.S. Geological Survey Professional Paper 234, p. 59-93.

Van Nieuwenhuise, D.S., and Kanes, W.H., 1976, Lithology and ostracode assemblages of the Peedee Formation at Burches Ferry, South Carolina: South Carolina Division of Geology Geologic Notes, v. 20, no. 3, p. 74-87. 